\title{
SALJUK ART AND MYSTICAL SYMBOLS CASE STUDY: METALWORKING
}

\author{
Nikoo Shojanoori \\ Faculty Member, Department of craft, Alzahra University, Tehran, Iran
}

\begin{abstract}
Economic, scientific and mystical growth in Seljuk era, and new developments create new changes in all areas, including the increase in quantity and quality of art. Fans of mystical movements were increased with attractive characteristics among different trades and ordinary people. The moral, social and religious situations were like that increasing discontent was created among the population and especially the scientists, poets and artists. Besides these problems, gradually merchant groups and even professionals could have increased their wealth and involved, as the wealthy part of society, in social and urban decision-making and exporting the products. Although high levels of production and temper tantrums by merchants, sometimes caused to make low quality products, but in the meantime, several works was created by Seljuk artists who influenced by the scientific and mystical atmosphere of the time, and were full of extraordinary innovation in concept and construction. In this period, the use of symbolism in art that there was from ancient times, but continues in the spiritual meanings. In this paper, we describe the situation of the Seljuk era and meanwhile trying to discover the cause or type of mystical symbols in metal works of the period using the case study and library tools to study metal products of the era. In the two examples of metal products from this period, it was found that all the designs of these containers, of plant or animal to human motifs and inscriptions, etc. are all coordinated, and indicate the mystical meaning of the flight of the soul, human evolution, destruction on God, love and the spiritual aspects and the like, and none of them are not useless and from a hobby or just for decoration.
\end{abstract}

Keywords: Seljuk era, Seljuk art, metal Seljuk, mystical symbols.

\section{INTRODUCTION}

Islamic art from the late first $\mathrm{AD}$ century was formed by aggregating and gradually making new combinations of shapes and artistic elements from newly collected, Unlimited deployment of arts such as calligraphy and pottery, and the creation and expansion of plant and geometric motifs, New interpretations and meanings of Islam by the refinement of shapes and arts contrary to the principles of Islam.

Due to the fact that what factors were involved in the creation of Islamic Art at the beginning and /or the history of art was paid less and more attention in each country and how it was created in the historical and description books of Islamic Art. Including the research and books, the book of Oleg Grabar can be noted about the formation of Islamic Art that on the issue, it is described how the Islamic art was formed and its development stages and even the designs used or rejected. Also, it can be pointed to the book by Professor Ismail synthetic epistemology of Ismail Bani Ardalan that it is discussed in a explicit way the details about how to synthesize by makers in a traditional viewpoint. Other books on the subject, it is noteworthy to point to the proceedings of the art of the Seljuk period by Hellen Brand, a prelude to a philosophy of Iranian art and proceedings queries Mahmoud Khatami noted that each of them is very valuable in its place and helpful for understanding the nature of Islamic art. 
The issue that has been largely ignored, is the religious, social, economic and political effects of any time on the course followed by the choice of his artisan status to create it. This is particularly of great importance relating to the art of Seljuk era with new designs or new and innovative products. Because paying less attention to what are the motifs and symbols created in the background, in the words of Ananda Coomaraswamy has caused: "The objects are nothing except the object, and self is nothing except ourselves." (Coomaraswamy, 2007: 60) In this study, we try to explain, using a case study approach, the two sample designs of metal containers of Seljuk era that are influenced by the situation of the time and mystical conditions of the artisan of this period. Research tools were Library resources and the study of metal designs, respectively. To achieve this goal, it was necessary to answer the following questions:

1. How was the atmosphere during the Seljuk era and what were the effects of the era on the people of that era?

2. What is the symbolic meaning of this term in the background pattern of metal work?

3. What were the causes of the use of mystical symbols in the art of this period, especially in the art of metalworking?

\section{HISTORY}

West Asia was the absolute power of Turk rulers of third century, then became its official governors. The first Turk dynasty in Iran were Ghaznavid Turks, who were important for Samanids as the supporters of the military of the Buwayhid, and gradually and in a short time, all of the eastern part of Iran, Afghanistan and parts of India were brought under their control, and had chosen Ghazni as their capital and their headquarter.

The second series of Turks hierarchies in Iran, were Seljuk that after a while were divided into several branches. "Above all, the Great Seljuk Empire (416-535 AD. / 1157-1037 AD) who came to power in North East of Iran and was developed toward the west and occupied Baghdad in the year 434 AH. / 1055 $\mathrm{AD}$ and ostracized Iraqi Shiite dynasty and captured Anatolia in the Battle of Manzikert (450 AH. / 1071 m) and finally found domination on the Syrian. "(Stinghaouzen, 2004: 371)

Catly says in an introduction to the history of Seljuks, "the Seljuk period in Iran was continued almost two centuries, in the second quarter of the eleventh / fifth century started with the conquests of the Seljuk continued to residence of Ilkhanids in a quarter of the nineteenth / VII century. "(Catly, 1997: 3)

\section{CIRCUMSTANCES OF SELJUK ERA}

The world of Islam in the early fifth century AD. / XI AD regardless of the Fatimid of Egypt, was in the political turmoil and social and cultural tensions. Iran in the Seljuk era also was influenced by the situation. Seljuk that were trying to impose the Turkish language and race to the residents after penetration and their domination of Iran, Azerbaijan and Anatolia, provided their authority by a complex chain of relationships and individual and family relations of the Sultan and Caliph to the lowest level of local government or Atabeg. This method results in an increase in the number of state courts and finally, take away the fabric of life and stability of government. New Seljuks were very conservative Sunni Muslims. Thus began the era of orthodox religion, for religious worship and fight mystical transformation and vivid and rich the Shia religion, despite all the problems, the view was magnificent. The attractive features of introversion and mystical movements, sense of responsibility towards society and the laws and by their own organization, the various guilds and ordinary people fans were growing. Social and economic situation is not so clear. Exploitation of farmers in the country had become common practice. In contrast, a group of businessmen and businesswomen and gradually even IT professionals looking weak local authorities, managed through trade and development, trade and export increased their wealth and involved in social and urban production and export decisions as the wealthy sectors of society. Because 
in this era of economic prosperity and however, the apparent calm, was an appropriate situation to grow the great individuals in the field of science and literature. During the Ghaznavid era, Ferdowsi's Shahnameh epic poems was completed and was donated to Mahmoud Ghaznavi. As scientists and the great Persian poets such as Ibn Sina, Abu Rayhan Biruni, Omar Khayyam, Anvari, Nezami and Jalaluddin Rumi, the poet of mystical poems born out all the time. However, scholars and poets had a direct impact on increasing awareness and education community.

The ethnic-religious differences caused tensions among the people so that in every city, neighborhood, and community created separately for each tribe, sometimes lead to conflicts and disputes between neighborhood was bloody massacres, as Rey turned on before the Mongols, conflicts and The city was devastated by a bloody conflict neighborhood. "Perhaps the best sign of the covenant Al-Ma'arri pessimistic poet (d. $435 \mathrm{AH}$. / $1057 \mathrm{~m})$ is Depravity and corruption of his covenant considered obsolete and insisted on the idea that is beyond human beings deserve it. "(Stinghaouzen, the same: 370)

Bagheri Khalili reasons to change the style and content of the epic poem the mystical The direct impact of this change in Circumstances of referred Seljuk and writes most of the Seljuk Turks, and many of the demonstrators to religion and promote corruption and Injustice and lying and deception were unhappy with Jamal-aldin Abd al-Razaq followed by a poem about it refers to:

Beware of the horrors, beware

escape! Wise people of this demon, escape

Death is its ruler, and pests are its king

oppression is his hero and persecution is his steward (Jamal-aldin Abd al-Razaq, 1983: 61)

He continued to know the existence of these problems and disorders as a major cause of the spread of Sufism and emergence of the poets such as Attar and Nezami and withdrew from court welfare by the poets as Nasir Khusraw and Sanaei is considered as the cause of discontent of the poets, scholars and the public grievances and suggest unworthy and incompetence and aggressive and bloodthirsty kings court considers abnormal situation. (2007: 69)

On the other hand, in the religious field, Turks knew of their obligation to eliminate the Shia, and replace the religious traditions, so gradually the apparent and the hidden layer or tradition and Shia emerged as a new culture that was the result of the spread of Ash'ari theology, Fiqh and Hadith, which comes as a result of this training, superficiality in addressing religion and Sharia as homework, and the other was demanded wide and shallow and overcome inherent in all aspects; and that despite the appearance of the people and cruel fight of gunpoint and widespread military schools, inner Qian of thoughts in the form of thought and conduct illuminated Shia and Sufi wisdom maintains and rich and ironic lyrics are cryptic and refers to himself knew the language. (Khatami, 2011: 151) And through various organizations and social solidarity with synthetic and classes, but the Seljuk rule, the active force of socio-religious force, and flashed again.

Written in verse and prose has a lot of mysticism in the sixth and seventh centuries, mysticism and philosophy attention of many ordinary people and artisans to Sufi and as a result, emerged groups with mystical ideas. In which the social environment Seljuk era full of mystical thought was based on the philosophy and reasoning. (Bolkhari, 2009: 109 108)

\section{ART IN THE AGE OF SELJUK}


In this era, because of increasing demand for high quality and sometimes unique products of Islamic countries, it is witnessed an extraordinary business growth and subsequent increase in wealth and business Iranian businessmen. Hence, in many cases, the group were richer than Local rulers, so that they have an impressive impact in many cases the cost or responsibility for supervision and construction of buildings and commercial products and crafts, to the owners of the caravan trade. It could order the plurality of voters instead in order to remain limited government, business and wealth accounts endless order for artists, thereby making unlimited variety of new architectural and significant variation in the quality and the quantity of handicrafts and commerce. Iranian architects innovations in this period had a broad impact and results. Seljuk extraordinary imagination of artists decorate types and designs, created wonderful works.

Invent or improve a variety of architectural styles and building plans with new applications such as schools, Tomb and Caravansary, new techniques or restoration and promotion of the arts such as pottery, Metalwork, textiles, calligraphy and geometric designs and plants are all telling skills and Frost artists Seljuk era. "Featuring Seljuk seeking diversity in design."(Hamidi, 93: 2011). In fact, one of the major developments of this period was the mixed forms and shapes that Stinghouzen mentions as "Meeting polyphonic". He says: "Even the insignificant decorating designs (ex. The protagonist winding arabesques and foliage plants) in the modulation frequency with the main motifs (such as labeling material reproductions and animal tools) often piles Micro-coil elements engulfed the entire project has a bright and enthusiastic appeal."(Stinghouzen, the same: 499)

On the other hand, as already noted, this period coincided with the rise Code of Chivalry Shiite and Sufi groups that had a significant impact on how artists. "Rules of magnanimity, generosity, not only was the army and agility, but also merchants and Artisans will also grow. Professional Skills and Technology Transfer from master to disciple there was usually a child were entrusted to master. As a result of the drawing and the generosity of The Taliban's early youth a specific industry ... each class taught drawing and Faith tells the class that the purpose of authenticating the originality of his career. "(Bani Ardalan, 2010: 70-69)

Including the scientific-mystical ideas and works of this period, the remaining documents are of the best sources of research on the history of the Seljuk period, the group known as The Brethren of Purity. It had a huge impact on businesses and artisans period. "Brothers in addition to scientific journey and dive into the thoughts and ideas, there were also a practical journey, on the basis of a system of education, teacherstudent and Regular device with different levels of learners and mentors were made Among the most important factors that influence the emergence of linkages between wisdom and Craft and art of chivalry in the history of Islamic civilization."(Bolkhari Qehi, 2009: 147) On the other hand, since "the art of the period in accordance with the prevailing thinking that is the spirit of that era."(Bani-Ardalan, ibid. 93) Given the moral perversion of the Seljuk period, are seeking interested individuals and Ethics around the market and the supply of goods, pottery making and Working without quality or poor-quality fabrics such as Kazerouni linen fabrics was learned in the fourth century historians of excellent quality and good market, but in the late fifth century would provide a quite different from the market. In this regard, the words of Bani Ardalan cited the author Farsnameh: "Before the dealers (sellers) bought Kazerouni loads and they were traded unopened in every city. Even then, it was possible to deal an unopened product ten times. So, because the loyalty of the people was destroyed, the trust feeling did not last anymore. "(Ibid: 72)

\section{MYSTIC MAKERS OF SELJUK ERA}

"Ladies and Gentlemen! All you have to connect the unseen world. When the tank was opened and the unseen into your mind Then your soul, the spirit, the soul, the rational soul and the body Decline of body organs. And thus both a work of art A poem, a piece of calligraphy, Appear sculpture or.... "(Dinani, E., 2009: 88)

Submit Date: 10.05.2016, Acceptance Date: 25.06.2016, DOI NO: 10.7456/1060JSE/013 
According to what was mentioned, it was determined that Seljuk era of the art, both quantitatively and qualitatively has been very good. This is apparently not coordinated by the social, moral, political or religious era. But it is said, on the other hand, this time with regard to trade, has witnessed the growth in many capitalists in commercial and industrial jobs or speak in a way that even in urban construction and /or export their products abroad and acted independently of government. On the other hand, due to the influence of the teachings of mystics and mystical groups of artists, the possibility of making products without the direct supervision of the court was created and however, due to the impossibility of clearly telling the hidden heart hypocritical bigot, constructing artifacts occurred in the role of the artist is mentioned as the guidance tool for people who were far from the truth. Bani Ardalan says regarding these artists and their products:

"Artists that were specific to the sensitivity of the senses and subtlety, they were fans of tradition of the divine and the divine experience are recorded at their handicrafts. Iranian mechanic tries through his good steward's behavior is desirable and commendable qualities. "(Bani Ardalan, ibid. 101-100)

But how the mystical aspects of the Seljuk era artists is displayed? To answer this question we need to be familiar with the meaning of mysticism. Spirituality means to reach and connect and unite with it. The mystic after receipt, locking his lips, and keep undiscovered most of the secrets because he believes the word and phrase does not fit with his lusts, and If they were fitted apparently, whose obscure and abstruse appears, thus the mystic keeps his silence and it is intuitive that he lost as an integral expression.

But humans instinctively seeks a relationship with others and mystic seeker is not an exception since receiving while he is not a matter of language, and is Illuminated as intuitive to express memories inevitably resort to metaphor, allegory and metaphor.

Compassion is the kin and relation

having relations with a strange man is not stable

Maybe both Hindu and Turkish language have compassion

Maybe two Turks were aliens

Then language itself is a confidant

communion is better than compassion

Without speaking and cue

hundred thousands of interpreters grew out of the heart (Masnavi of Jalaleddin Rumi)

The artist in his artistic creations that arise from witnesses is placed in a pure moment of awareness and knowledge beyond her. That's why sometimes knows this secret is and where it comes from and if you did not find this issue of knowledge, it cannot express the expression is more interpretive. The principle of the indivisibility and indescribable expression is illuminated. Hence the interpretation of metaphor and allegory, and it brings the same functionality that the expression of a mystic intuition and selfillumination. (Zarabi 2005: 147- 135) "The demand and enthusiasm of Contact, in the balladry of the reed of Rumi and A stranger Nostalgia of Suhrawardi, in most explicit language has been said the story of a strange pilgrims from his moder country are confused and astonished in remote nostalgia.... This is the ascension and thirty birds enthusiasm to go before the Phoenix have no other motive. "(Sattari, 2010: 121) 
That's why the Islamic Art has rich wise support, philosophy and mysticism, all is full of symbolic images and forms of existence. Because the Muslim artist, what is intuitively understood and cannot describe it in words, with measures such as metaphor and allegory, to set the tone. Because: "With no symbolic language than to speak it cannot be the ultimate truth." (Coomaraswamy, the: 97)

"Not only is the production of handicrafts such as pottery objects, Metal and textiles, woodwork, etc., but also the tools of the craft, Rich in symbolic meaning implies a spiritual place we find them."(Cable, 2001: 152) Even in the midst of a busy decorating Islamic art, whether or arabesques and geometric patterns Or the complexity of the line, according to Grabar exercise Practical and thoughtful meditation. "Practice means that it is made more Severable from the formulas (such as the ability to separate or geometric arabesque the smallest repeating unit) and at the same time, consideration is because it is nothing more than what can be seen there."(Grabar, 2000: 225-218)

On the same course or destruction of God and of God's existence in the expression and exposition, it appears in encrypted form. Alliance lovers, converted to plant seeds, Burning Butterfly (spirit) in the flame of the candle (divine beauty) and firewood in Nar destruction and disappearance of light and shadow Drop in the sea or in the form of a love story of Layla and Majnun and Yusuf and Zulaikha and Solomon and Queen of Sheba, Vamiq and Azra, Salaman and Aabsal, Shirin and Farhad....which all belong to the world of love and passion and tension and attraction are expressed. (Sattari, ibid. 144)

\section{STUDY OF METAL CONTAINER OF SELJUK ERA ICONS IN TWO SAMPLES}

Fortunately, from the Seljuk period remains the most beautiful metal work each alone is worthy of consideration, however, since the study and followed all the products in one article is impossible, so in this study, only two of these works, the designs of the application and almost their design was different, and the other having the same designs with other metal containers were this time examined.

\section{METAL WORK IN SELJUK PERIOD}

began with the emergence of a bright Seljuk the Islamic metalwork. Metal artists of the era in Herat, Ghazni, Merv, Nishapur and Tus was converted well by highlighting organisms, interlacing, Inlay and the use of a variety of decorative motifs such as geometric designs, Arabesque and fauna, natural or dramatic fiction and finally Innovation The letters, usually at the end of the animal or human head was turned their unique skills and creativity.

EXAMPLE NUMBER ONE; shows a beautiful brass candlesticks of the sixth century AD. (Figure 1) that is decorated on the upper edge of the candlesticks to highlight the code and just below the featured band is made just below the lens attached to it, finned cylinder is located. The main body of the candlestick in the form of hyperbolic Field Under this section is made right at the edge of the bird eighteen prominent installed. The birds in a row just below the edge of the candlestick, the arabesque bar is inlaid. Arabesque is made a row in the bar attached to the relief valve. Lions row in a row following inscription written and graphic content of the prayers and litanies below the inscription decorated highlighting three rows together that made Tupac Scored seven points is multiplied to form on the surface of each sphere. Decorated with a row again after Tupac other line, tap and Arabesque is repeated. 


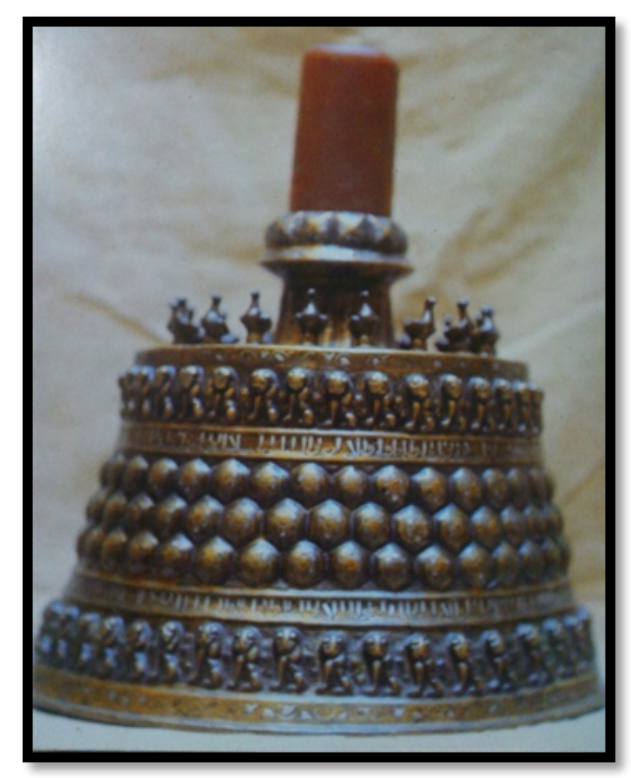

Figure 1. Brass candlesticks, Qrn7-6 ah, the Cairo Museum, the references (Najafi, 1986: 631)

\section{ICONS IN CANDLESTICK}

Bird: symbolize the soul, means that soul sees itself as inherently winged Planetarium, which is home to the world, flying, and this is a very ancient secret. Identity or self-image as a chicken or a winged creature appears, also in the works is closed Suhrawardi, The Epistles of Ibn Sina and Attar in Masnavi "(Sattari, the same: 122-119)

Depending on the function of emitting light candles and also compatible with Airy and light and airy with a flying bird, bird diversity and homogeneity Especially the mast head and body, you can see an analogy of the kingdom of heaven and Soul is flying to the other side. In the book of graphic symbols in the symbol of the bird: "Bird-wide symbol of the soul, especially when he ascended into heaven after death." (Hall, 2001: 39)

Furthermore, the birds symbolize the spiritual, symbol, and the angels are superior. Passenger birds, like thirty birds in Farid al-Din Attar's poems, are in search of meaning. The Conference of the Birds of the sense of logic and hard to describe the mystical sorrows and the difficulties of the truth direction are used. Bird also interpret the immortality of the soul, as well. Shahbazi Spirit is likened to the sound of his master calls, or bird cage captive earth, and so on. Hence, the Muslim mystics, often rebirth or spirit to flourish bird cages have been abandoned, Resemble. (Shovalieh, 2009: 201-197)

Lion: The meaning of the use of two rows of 44 prominent figures half lion, Because of the association with a sun symbol, the lion's mane, light and resurrection (according to some ancient ideas), will apply. The Knight of the Lion symbol explains that "the mighty lion, king, Sun symbol, and extremely bright, and full of virtues and the king of animals Vices from office "(Shovalieh, ibid. 111) Hall of status symbol of the lion In Ancient "The Lion and the Sun in the image Mitra (Sun) are seen together. The snake that is wrapped six times around itself, the symbol of the sun through a solar eclipse and a seal here, the Sun is his hand. "(Hall, Ibid. 61) also pointed out that the title of Imam Ali (pbu) is God's Lion or Assadullah.

Arabesque: Arabesque design is about the role of craft in the majority Islamic era. This role is sometimes covering the entire surface as the main decorative effects and was or in the field below or beside the main role and sometimes like candlesticks above it was created as a decorative border. But in any case, its symbolic role well demonstrated, Even if the author did not consider it such a purpose. The Arabesque "is 
a form of enlightenment the complexity, but the rhythm is not arabesque forms. A kind of prayer with an endless repetition of a theme, markup from a mental note. Arabesque has neither beginning nor end, and cannot be seeking to start and end. Because of his desire. "(Shovalieh, ibid. 184)

Inscriptions and Letters: The value in Islam is quite clear because due to go between to illustrate the divine miracle of Islam, the Qur'an. Imam Ali (pbu) had commands and specific recommendations to improve his writing Line of his scribes said to themselves and their children the best time to have written the Koran. Emphasis on Islam and the infallible word is to educate and also do anything to perfection, besides the high position of the Quran led Muslim calligraphy and it turned out to be the best in architecture and crafts Most of use. So that it can be said "No Muslims as calligraphy art artistry in Education Is not effective. Arabic calligraphy in a horizontal row from left to right Find the right zone, namely labor and Thus, instead of the left path from outside to inside. Pan and swirl wavy lines and the like will be mapped and the development of the vertical line on which are permanent ink of the existence or life. Which is the horizontal movement of its genesis, Interlinking and stability tends to form different words. On the other hand, the horizontal expansion or overcome these letters and the circular motion and reduce mental writing. The vertical lines and horizontal lines look as if the essence of existence rests are a source of diversity. "(Burckhardt, 1986: 62-57)

Scholars' adherents of view, the whole world is made up of letters, but this character is manifested in humans. 28 letters of the alphabet in the Qur'an. "According to Abdul Bastami, Sufi Master, given the nature of the main characters and their star will attain inner knowledge of the experience that is unattainable in other ways. Letters are inspired one way or another successor In front of stunned mystic, light savory explore and understand the potential consequences of the present and future are shining. "(Shovalieh, ibid. 13)

United circles or spheres: the continuity of the candlestick is reminiscent of parts of the world at the same separation according to the philosophy underlying theme in Islamic art can be seen, namely: unity in diversity and Multiplicity in unity. In other words, there are a large number of times, and especially beat seven other small hemispherical surface of the sphere, It can be an allegory of the stars who exalt God and they always remind people to see God's glory.

All the particles involved in the unseen world,

talking to days and nights

We are hearer and testifier and wakeful

we are silent with the strangers(Masnavi of Jalaleddin Rumi)

EXAMPLE TWO; a pitcher of Herat built in 576 AH. This brass pitcher with a long neck and decorations is highlighted by inlaid silver and copper. (Figures 2 and 3) Using the inlay art on the body of brass dish, not only makes an extraordinary beauty on the dish, but also through worthless material within turned off this feature, the value of the art works of an artist not its material is a valuable feature of Islamic art. Although the construction of the pitcher, Herat has been dominated by Ghurid dynasty, but according to the researchers, metal products made in this state were entirely based on the Seljuk metal working style and usually on the order of traders. What makes this pitcher as special, not only its remarkable beauty, but at the same time is the use of a set of meaningful decorations. Rachel Ward notes about the same features of the above pitcher, while using the words of the pitcher manufacturer that are inlaid on the tube of the pitcher that with regard to the issues raised in the above verse, motifs used in pitcher purely symbolic and in other words, tracing the pattern of expression of the pitcher manufacturer has to follow a certain concept. Considering the above, and here to help answer research questions, Full 
text is written into our quote. The value of the new and inlaid brass dishes, inlay with a tasteful inlay master, the other pitcher long tube is shown at the Museum Tiflis, dated 1182-1181/578-577 that was signed.

My pitcher is graceful and beautiful...

At a look, it has the spirituality and life in it.

And the water of life is flowing from it.

The flow of the water flowing

Each time, the joy of its new...

In the next century, as it can make?

Although it may be a magnificent body of the seven heavens,

But the guard who works this way.

Let kindness and compassion to the person who made such pitcher to collapse...

$[\mathrm{He}]$ will be happy if this pitcher to forgive a friend.

And the inconvenience and hardship if it is an enemy to surrender.

Icon writing poetry to point out that this dish was highly symbolic. Military, the source of life that is hidden in darkness, the sun is likened to the source. This pitcher perhaps symbolizes the source of life from which flowing water or source of the sun, this is shown by the writings of body groove radial stripes around the neck of the container, Displays and recycling plants by the radiation beam lights on the surface of the container to be seen. In these circumstances, the real and imaginary images of animals, birds and fish on the pitcher show spiritual and material worlds simultaneously. (Ward, 2005: 77-76)

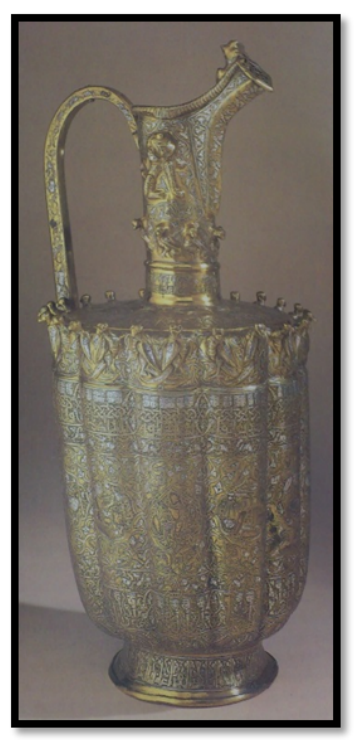

Figure 2. Inlaid pitcher, the Hermitage Museum, Reference: (Ward, 2005: 78) 


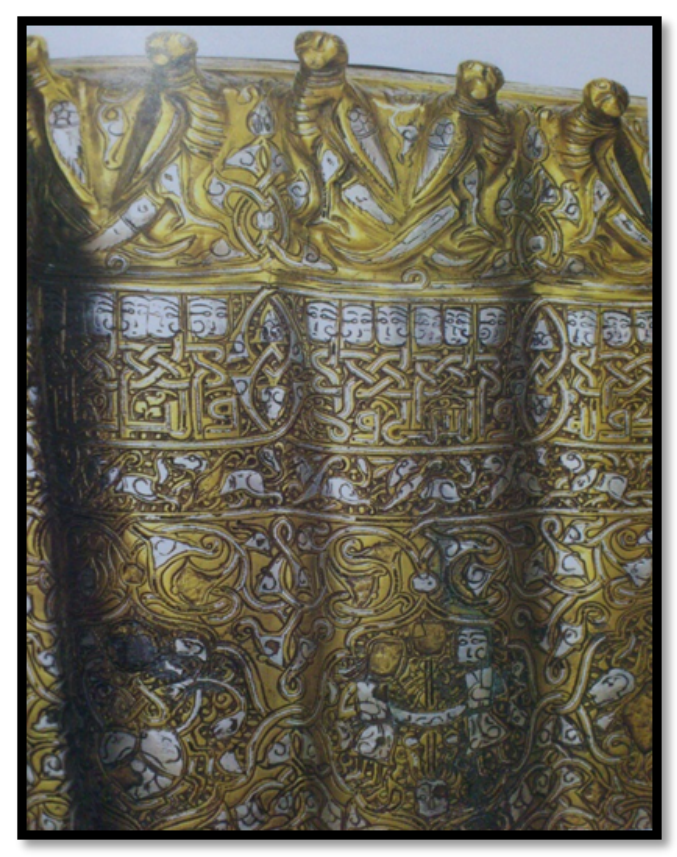

Figure 3. Part of pitcher body based on Figure 2: (Ward, the same: 70)

\section{ICONS IN PITCHER}

As part of the candlestick on the tap symbol, Arabesques and scrolls will be discussed in this section to explain other designs.

Hawk or eagle: hawks, eagles and other soar birds have always been a symbol of solidarity with the sun. "Eagle king of birds is the symbol, herald of the gods or God's successor, Sun or celestial fire and the only one who has the courage Look directly at the sun without burning eyes "(Shovalieh, ibid. 286)

On the other hand, it seems on the head or mouth of the bird around the pitcher, there is a coating or hood that is used to cover the head, birds of prey. "The dream symbolizes light, someone who is living in darkness, light brings. The hood of falcon picture of prisoners and the sign was hardly a mystic puzzle. Light symbolizes the windward mark and the esoteric knowledge. "(Shovalieh, ibid. 486)

Another point in the birds, bringing them back to back doubles down on both the Arabesque is a complex branches among them. The role of the face or back of the animal tree of life also in the midst located, as you know the history of ancient art. Given the set of symbols that have already mentioned this symbol can mean the mystics or the enjoyment of eternal life is protected from light.

Kofi node with face: using the form at the pitcher Kofi knotted lines per blade or Interweaving written at the end of six if the woman is given. Interlace lines of favorite designs tattoo artists Seljuk era, especially in the art of metal or is inlaid. This role, sometimes individually and sometimes in combination with arabesque or inscription is given. Shovalieh notes about the symbolic meaning of this role, "says interlacing is invited to enter to partake in the mysterious unity, and somehow the spirit seeker identify not only with the spirit world, but also the nature of God.'(Ibid: 215)

But as a man who is a symbol of wisdom and utterance, can be traced to some purpose. First, if the whole world would be reminiscent of praise to God. «Swims his seven heavens and the earth and of the deeds, 
The Turkish Online Journal of Design, Art and Communication - TOJDAC July 2016 Special Edition

and that it is nothing but praise and glorification but not rewarded ...» The seven heavens and the earth and all that is in them exalt him, and nothing but the glory of God with praise, he says, but you not find them in prayer. (Israel / 44)

On the other hand, one can imagine that this particular pattern of six per blade, Symbol of the six planets of the solar system in which are located the blades of the pitcher beams. Symbol of Venus and moon motifs in the form of a woman, as a symbol of aesthetic and was used as luck symbol by Muslim artists frequently because "The planets Venus and especially Venus among the ancients as a goddess of beauty and little luck have also been discussed. Some scholars of Islam in addition to Venus and Moon symbolizes the other planets of the solar system, including Saturn, Jupiter, Mars, Mercury is also considered feminine and They are known as he of six bride or six Khatoon "(Hosseini, 2012: 74-73) In addition to the mentioned above, since the faces of those who seem to have a way of Allah, the reflection of God can be seen, so that the person with more virtue and more faith, his face is bright and beautiful, it can be concluded Beautiful pink light of the sun can be real or symbolic of divinity, Divinity latent or explicit. Shovalieh says in this regard: "It is a symbol of the evolution of living things, from shadow to light. By the way, if you can shine as if an angel of evil has been cleaned ... and like a door that opens into the unseen, the lost door keys, etc. Mystics often cry out to God to show his face. "(Ibid: 186 -185)

Winged rabbit and dog: is one of the most interesting designs in the pitcher in my opinion, Image of winged rabbit and dog, looking each other in town. Because all the designs that has been described here, has the symbolic and mystical meaning, undoubtedly, the use of animal motifs, in the form of a winged semi-runner looking for each other and that has a specific meaning which cannot have a relationship with other symbols.

Since the book Hall, a rabbit, a symbol of fertility and lust for learning and In contrast to the dog associates Mitra (Sun) sees the guard and messenger of the gods. '(Ibid: 45 and 52) Perhaps the pitcher manufacturer is an artist, depicting the symbol of the people who live although a post-worldly qualities, but as the sun goes looking for partner Times greater than its past, the Balinese have to fly into the sun. This means, in particular with respect to the plurality of rabbits against dogs, more verifiable.

Design of men and women together: the design that is in the middle of the pitcher medallion has shown the Young men and women that are taken jointly a fabric, the woman looked at the ground and the man watches on the woman's face. The design that has shown emotional or romantic relationships between men and women, is the most favorite scenes according to mystical poets and artists singing songs in Seljuk period, because they represent the earthly love as the highest love means divine love, the extinction and survival on God that is expressed with the help of symbols and password. Thus, the union of lover and beloved is expressed by examples like "Convert to plant seeds and wood burning permits (spirit) in the flame of the candle (divine beauty) and Firewood destruction of Nar and fading light and shadow in the drop in the sea Or a love story of Layla and Majnun and Yusuf and Zulaikha and Solomon and the Queen of Sheba, Vamq and Azra and Salaman and Aabsal and Shirin and Farhad, who all belong to the world of love and stretch ......attraction and desire. Love of Majnun Sofi beliefs displays maximum expression, as if the beloved is the mirror of lover, lover also in return sees his beauty only in the eyes of his beloved. "(Sattari, ibid. 159-139)

\section{CONCLUSION}

Of a material setting that has already been stated, it became clear that the social and religious conditions of the Seljuk period, despite all scientific, economic, artistic advances suffered by several of the ravages and this has led to Sufi mystic and realistic desires to grow increasingly popular. Their Brethren bodies such as the manifesto of the Union as a youth and finally, a plurality of poets and philosophers and scholars, Gnostic, including factors that the artists of this period are more familiar with mysticism and its meanings. Since the Seljuk era conservative zealots and mystic any word meetings against religion and 
novelty considered unforgivable fiercely, the Council and consequently the Seljuk artists Impossible to describe in terms of symbolic motifs mystical perceptions, their expression.

Since the work place in Islamic art, especially the Seljuk art is vain, Whatever makers created this period, his body of work has used motifs, All have a specific purpose and a sense of place and useless or of the hobby, and a role is created. This is particularly so random sample survey designs of metal works of this period, the more confirmed. In both objects, for all the motifs used, can be found mystic meanings Chainlike, meaning related to each other or support and reinforce each other.

Candles that are the instruments of illumination, including bird motifs, prayer scrolls, arabesques, milk and spherical shapes and What finned body of the pitcher to keep the fresh water and an arabesque, and the lion, together with the candlestick and if the cursor scrolls knotted, Men and women together, hawk or eagle winged animals and runners, Entirely on the type of application and designs employed, The purpose of inducing mystical meanings which cannot express it in the head.

\section{REFERENCES}

Bagheri Khalili, AA. (Summer 2007), Happiness in Iranian culture and literature, national literature, No. 30 .

Bani Ardalan, Ishmael. (2010) Epistemology handicrafts and art search technology concept, Chapter October, Tehran.

Bolkhari Qehi, H. (2009), queries the nature of Islamic Art (Proceedings of course speech) - the first book, the effort Hadi al-Rubaie, Institute of writing, translation and publication of works of art "text", Tehran.

Burckhardt, Titus (1986) Islamic art speech translation Nia M. Ragab, Soroush, Tehran.

Cable, Brian (2001) Secrets of religious art, religious art Proceedings of the First International Conference, arranged and edited by Mehdi Firuzan, Soroush, Tehran.

Coomaraswamy, Nandra (2007) and Eastern Christian art, philosophy, translation and commentary Amir Zkrgv, Academy of Art, Tehran.

Dinani, GH (2009) queries on the nature of Islamic Art (Proceedings of course speech) - the first book to try, Hadi al-Rubaie, Institute of writing, translation and publication of works of art "text", Tehran.

Etinghowzen, V., Richard Graber (2004) Islamic Art and Architecture 1, translated by James Azhand, ch 4 , side, Tehran.

Grabar, Oleg (1980) Formation of Islamic Art, translated by M. unity, Institute for Humanities and Cultural Studies, Tehran.

Hamidi, B. (2011 April) array of decorative stucco Seljuk period, Book of the Month Art, 151

Hosseini, Seyed Hashem. (2012 Summer) analysis of samples from women designs on pottery of the Islamic era, women in culture and art, Volume IV, No. 2. Scientific-Research

Katly, Margarytav Louis Hamby (1997) BS Seljuk art and art history collections, translated by James Azhand, Molly, Tehran.

Khatami, Mahmoud. (2011), a prelude to a philosophy of Persian Art Institute of writing, translation and publication of works of art "text", Tehran.

Nursing, J. (2010) Introduction to Cryptology mystical, g 4, Publishing Center, Tehran.

Zarabian, Mohammed Ibrahim. (1384), the language of mysticism: An Analysis of the function of language in expressing mystical perceptions, Bynadl, Tehran.

Ward, Rachel (2005) Islamic metalwork collection of Islamic art, translated by M. pleasant one, Institute of Islamic Studies, Tehran. 